\title{
Wiedza czy stereotyp? Kobieta z zespołem Turnera w szkole i na uniwersytecie
}

Wstęp

Niniejsza praca oparta jest w większej mierze na doświadczeniu osobistym niż na mądrościach wyczytanych w tym czy innym podręczniku. Jednym z jej celów będzie wręcz namówienie czytelnika do przyjęcia sceptycznej postawy wobec informacji zawartych w książkach - także tych naukowych. O konieczności łączenia teorii z doświadczeniem przy próbach opisania zjawiska niepełnosprawności mówi Havi Carel, amerykańska przedstawicielka filozofii medycyny, w swojej książce Illness. The cry offlesh. Przeżycia związane $\mathrm{z}$ chorobą nowotworową płuc kierują autorkę ku fenomenologii oraz starożytnym koncepcjom cierpienia ${ }^{1}$.

Osoba niepełnosprawna, słuchając o swojej przypadłości na lekcji biologii lub na wykładzie, zostaje zmuszona do skonfrontowania własnej wiedzy z podręcznikowym obrazem rzeczywistości. W głowie pojawia się pytanie odezwać się czy milczeć, przedstawić się jako „żywy okaz” czy też zniknąć w tłumie? Jeśli niepełnosprawność jednego z uczniów (studentów) jest

1 Zob. H. Carel, Illnes. The cry of flesh, Stevenage 2013, s. 9-15. 
178 widoczna, prowadzący zajęcia może czuć się zobowiązany do „specjalnego potraktowania" tematu. Nauczyciel może postarać się o dodatkowe materiały lub zaprosić podopiecznego do wystąpienia w roli eksperta.

Sytuacja przedstawia się inaczej, gdy wszyscy są przekonani, że grupa składa się z samych „normalnych”, zdrowych ludzi. Wykładowca nie zawsze ma wykształcenie medyczne. O chorobach genetycznych i różnego rodzaju niepełnosprawnościach uczą się nie tylko przyszli lekarze, lecz także studenci pedagogiki, psychologii, socjologii, a nawet etyki czy filozofii. Część $\mathrm{z}$ nich to osoby niepełnosprawne. Dla nich wykład czy dyskusja na temat etyki medycznej mogą stać się okazją do sprawdzenia, jaki obraz człowieka chorego mają w głowach „zwyczajni” ludzie.

Przyszłam na świat $\mathrm{z}$ zespołem Turnera. Jest to choroba genetyczna dotykająca jedynie kobiety, związana $\mathrm{z}$ brakiem lub wadliwą budową jednego chromosomu X. Podstawowa wiedza o tej chorobie wymagana jest już na poziomie gimnazjum. Obraz kobiety o kariotypie XO przedstawiany w polskich szkołach jest często niepełny, a przez to niejednokrotnie skrzywiony. Błędy w książkowych definicjach mogą być z łatwością wykryte przez lekarzy specjalistów, a także przez ich pacjentki. Podobnej wiedzy nie można jednak oczekiwać od ogółu uczniów i studentów, którzy nie muszą koniecznie interesować się genetyką czy endokrynologią. Tym bardziej należy dbać o to, by informacje dotyczące życia osób niepełnosprawnych, zawarte w popularnych opracowaniach, były całkowicie zgodne z prawdą i nie utrwalały stereotypów.

\section{Zespół Turnera - podstawowe informacje}

Zespół Turnera to uwarunkowany genetycznie zespół wad wrodzonych, spowodowany brakiem jednego chromosomu X lub też jakąś aberracją w jego obrębie. Dotyka średnio jedną na dwa i pół tysiąca urodzonych dziewczynek. Przyjmuje się, że monosomia chromosomu X w większości przypadków kończy się poronieniem w pierwszym trymestrze ciąży.

Kiedy możemy podejrzewać zespół Turnera u dziewczynki? Badania prenatalne wskazują zwykle na wrodzone wady serca (występują u ok. 23-40 proc. chorych) i nerek (pojawiają się u ok. 25-39 proc. chorych)2. U noworodka

2 Zob. K. Łącka, Zespół Turnera - korelacja pomiędzy kariotypem a fenotypem, „Endokrynologia Polska" 6 (2005) 56, s. 989. 
stwierdzamy niską masę urodzeniową, anomalie układu kostnego oraz obrzęki limfatyczne stóp i dłoni. Zdarza się, że dziecko pozostaje niezdiagnozowane przez długi czas. U dziewczynki w wieku szkolnym obserwujemy niskorosłość i opóźniony wiek kostny (spowodowany niedoborem hormonu wzrostu), u nastolatki zaś - opóźnione dojrzewanie płciowe i brak pierwszej miesiączki.

Brak chromosomu X odpowiada za pierwotną niewydolność jajników oraz wady w budowie narządów wewnętrznych. Poza nielicznymi wyjątkami (2-5 proc.), kobiety z zespołem Turnera są bezpłodne ${ }^{3}$. Niedobór hormonu wzrostu i estrogenów w wieku dojrzewania prowadzi do problemów z układem kostnym (zmiany osteoporotyczne). Ponadto stwierdza się częstszą zapadalność na choroby tarczycy, cukrzycę, zapalenie ucha. Pojawić się mogą również wady wzroku i kłopoty z układem pokarmowym ${ }^{4}$. W wyglądzie zewnętrznym oprócz niskiego wzrostu zwraca się uwagę na krępą budowę ciała, szeroką klatkę piersiową i niską szyję (w obrębie której mogą pojawić się dodatkowe płaty skórne, tzw. szyja płetwiasta). Wśród cech charakterystycznych, lecz mniej widocznych, wymienić możemy nietypową budowę paznokci (60 proc. badanych), włosy rosnące nisko na karku (40 proc.), "gotyckie” podniebienie (40 proc.) oraz znamiona skórne (25 proc.) ${ }^{5}$.

W popularnych opracowaniach często spotkamy się z informacją, iż zespół Turnera łączy się z niepełnosprawnością intelektualną. Tak naprawdę obniżony poziom sprawności umysłowych dotyczy jedynie 5 proc. kobiet z tym zespołem ${ }^{6}$. Zdiagnozowane dziewczynki wykazują dominację inteligencji werbalnej nad wykonaniową. Oznacza to zwykle lepsze wyniki z przedmiotów humanistycznych niż z matematyki. Sama choroba (poza nielicznymi przypadkami) nie stanowi przeszkody w podjęciu normalnej nauki szkolnej, a nawet studiów wyższych. U badanych pacjentek stwierdzono natomiast częste występowanie zaburzeń natury emocjonalnej. Czasami są one wynikiem niezadowolenia z własnego wyglądu. Problemy tego rodzaju mogą zostać rozwiązane po zastosowaniu hormonalnej terapii zastępczej, która między innymi poprawia ogólny wygląd sylwetki.

Brak stabilności emocjonalnej może być spowodowany również brakiem akceptacji społecznej. Niski wzrost, słabo zaznaczone cechy kobiece, w końcu ogólne problemy ze zdrowiem - wszystko to sprawia, że Turnerki

3 Zob. K. Łącka, Zespół Turnera..., dz. cyt., s. 988.

4 Zob. K. Łącka, Zespół Turnera..., dz. cyt., s. 989-990.

5 Zob. K. Łącka, Zespół Turnera..., dz. cyt., s. 988.

6 Zob. K. Łącka, Zespół Turnera..., dz. cyt., s. 990. 
180 powszechnie uważane są za osoby niedojrzałe, infantylne, mało atrakcyjne. Po zastosowaniu terapii hormonalnej ich wygląd zwykle nie odbiega od ogólnie przyjętej normy, mogą jednak wydawać się młodsze, niż są w rzeczywistości. Otoczenie nierzadko przyjmuje wobec nich postawę lekceważącą („ona sobie z tym nie poradzi”) lub nadmiernie opiekuńczą („lepiej zrobię to za ciebie"), co z pewnością nie ułatwia nawiązywania zdrowych relacji. W końcu trudnym emocjonalnie wydarzeniem jest samo zapoznanie się z diagnozą (szczególnie z informacją o bezpłodności).

\section{Turnerka w szkole}

Najważniejszym wyzwaniem, przed którym staje dziewczynka z zespołem Turnera podejmująca naukę szkolną, jest nawiązanie prawidłowych relacji społecznych. Nieobecności spowodowane wizytami u specjalistów są źle postrzegane - zarówno przez rówieśników, jak i przez nauczycieli. Jeśli dziecko przewlekle chore nie ma widocznych oznak niepełnosprawności ani też żadnych większych problemów z nauką, postrzegane jest jako zdrowe. Prośby o dostosowanie wymagań na lekcjach wychowania fizycznego albo o możliwość pisania sprawdzianu w innym terminie grupa klasowa może uważać za nieuzasadnione wymysły, nawet gdy uczeń za każdym razem przedstawia stosowne zaświadczenia lekarskie. Podobne problemy mogą dotyczyć tych dziewczynek z zespołem Turnera, które są „typem mozaikowym" (u dziecka stwierdza się występowanie dwóch linii komórkowych jedną z prawidłową liczbą chromosomów, drugą z jednym chromosomem X brakującym lub uszkodzonym). Nie odbiegają wyglądem od pewnej przyjętej średniej (zwłaszcza przy wcześnie rozpoczętej terapii hormonalnej) i pozostają w normie intelektualnej.

Dla osoby wchodzącej w wiek nastoletni sprawą najwyższej wagi staje się potwierdzenie własnej samodzielności i niezależności oraz zdobycie akceptacji społecznej. Pierwszym kryterium, które grupa rówieśnicza bierze pod uwagę przy ocenie „dorosłości”, jest wygląd. Dziewczynka o niskim wzroście i słabo zaznaczonych cechach kobiecych może zacząć czuć się niepewnie w kontaktach społecznych. Problem nasila się, jeśli osoby dorosłe z jej otoczenia przyjmują wobec niej postawę nadopiekuńczą. To, co rodzina chorej przewlekle nastolatki uważa za przejaw troski, na zewnątrz może być odbierane jako śmieszne, niepotrzebne, a nawet szkodliwe. Dorastająca dziewczyna spotykająca się z takim traktowaniem może odczuwać wstyd, 
narzekać na brak kontroli nad własnym życiem i dłużej uczyć się samodzielności.

Kolejnym źródłem stresu mogą być lekcje wychowania fizycznego czy biologii. Niechęć do zajęć sportowych będzie spowodowana niską sprawnością fizyczną (małe i słabe dłonie, krótkie nogi, ograniczenia wynikające z chorób towarzyszących) lub też brakiem akceptacji własnego ciała (brak kobiecej sylwetki, pierwsze problemy z nadwagą). Lekcje biologii także mogą być trudnym przeżyciem dla dziecka obciążonego genetycznie lub niepełnosprawnego, zwłaszcza jeśli informacje na temat poszczególnych schorzeń prezentowane na zajęciach są nieprawdziwe bądź odbierane przez chorego jako krzywdzące.

Warto przyjrzeć się definicjom, jakie zawarte są w podręcznikach i repetytoriach dla gimnazjalistów i licealistów. W Tablicach Wydawnictwa Greg zespół Turnera pojawia się w tabelce przedstawiającej szereg chorób, będących skutkiem mutacji w obrębie genomu, tuż obok zespołu Downa i zespołu Klinefeltera. Opracowanie podaje takie objawy monosomii chromosomu X jak bezpłodność, niski wzrost i upośledzenie umysłowe ${ }^{7}$. Pada również stwierdzenie, iż przy tej chorobie mamy do czynienia $\mathrm{z}$ „osobnikiem płci żeńskiej”. Poważne zastrzeżenia budzą same wyrażenia używane przez autorów tej definicji. W mojej opinii są to określenia przynajmniej kontrowersyjne, jeśli nie obraźliwe. Zamiast mówić o „osobnikach”, powinno się w tym przypadku mówić o „kobietach”. Mądrze byłoby również, zgodnie z najnowszymi tendencjami w pedagogice specjalnej, zastąpić „upośledzenie umysłowe” terminem „niepełnosprawność intelektualna”.

Wśród cech typowych dla zespołu Turnera autorzy opracowania wymieniają obniżone zdolności w zakresie operacji myślowych. Badania pokazują, że deficyty w tej sferze dotyczą zaledwie kilku procent chorych. Nie wspomina się natomiast o wadach serca czy zwiększonej podatności na choroby tarczycy, mimo iż są to problemy dotykające zdecydowanej większości kobiet z tym zespołem. Ogólny obraz dziewczyny z monosomią chromosomu X, jaki wyłania się z podanej definicji, jest dość negatywny. Typowy uczeń gimnazjum, niezorientowany w dziedzinie endokrynologii, po zapoznaniu się z taką tabelką wyobrazi sobie niezbyt rozgarniętego karła. Prawdopodobnie nie przyjdzie mu nawet do głowy, że dziewczyna $z$ tą chorobą mogłaby chodzić z nim do jednej klasy.

7 Zob. Tablice. Matematyka, fizyka z astronomia, chemia, geografia, biologia, Kraków 2012, s. 471. 
Obawiam się, że tego typu skrótowe definicje mogą prowadzić do powstawania stereotypów. Może się wydawać, że podobne błędy w podręcznikach na dłuższą metę nie są szkodliwe, ponieważ uczniowie i tak zapominają je bardzo szybko. Trzeba jednak stwierdzić, że wiedza na temat chorób genetycznych w społeczeństwie jest niska i powierzchowna. Może to prowadzić do powstawania nieporozumień i zabawnych mitów.

Częsty przypadek to mylenie zespołu Turnera z zespołem Tourettea. Ponadto media co jakiś czas donoszą o „chłopcu z zespołem Turnera” (czyli z niedoborem hormonu wzrostu), zaś popularne seriale lubią opowiadać bajkowe historie o trzydziestolatkach, które „zatrzymały się w czasie” i wyglądają jak dwunastolatki (mit „wiecznych dziewczynek”). Nic dziwnego, że typową reakcją na deklarację „mam zespół Turnera”, z jaką spotykają się kobiety o kariotypie XO, jest szok rozmówcy.

Jeśli dziewczyna jest „typem mozaikowym”, swoim „wyznaniem” zadziwi wielokrotnie także lekarzy. Dermatolog, ortopeda czy nefrolog w ciągu wieloletniej praktyki mogą nigdy nie spotkać się z pacjentkami obciążonymi monosomią chromosomu X, dlatego inteligentna studentka o wzroście powyżej $150 \mathrm{~cm}$ może nie pasować do zakurzonej definicji, z jaką zapoznali się w czasie studiów. Lekarze rodzinni i położne powinni być szczególnie przeszkoleni w rozpoznawaniu objawów wszelkich wad genetycznych, w tym zespołu Turnera, tak aby chore dzieci były możliwie wcześnie kierowane do specjalistów. Czy należy w związku z tym rozpowszechniać badania prenatalne? Kontrowersje związane z badaniem dzieci nienarodzonych omawiam w dalszej części pracy.

\section{Turnerka na uniwersytecie}

Dziewczyny z zespołem Turnera mogą preferować zadania werbalne i gorzej radzić sobie z orientacją w przestrzeni. Oznacza to jedynie tyle, że chętniej wybierają kierunki humanistyczne, społeczne, a nawet medyczne niż typowo techniczne czy inżynierskie. Warto zauważyć, że podobne zainteresowania wykazuje wiele zupełnie zdrowych kobiet. Szanse na sukces edukacyjny w ich przypadku zależą od tych samych czynników co w przypadku zdrowych uczniów, to znaczy od właściwego wyboru szkoły i poziomu motywacji. Niepełnosprawność intelektualna dotyczy kilku procent pacjentek z tym zespołem - reszta, to znaczy zdecydowana większość, może myśleć o normalnej nauce w szkole średniej i wyższej. 
Czego może dowiedzieć się o swojej chorobie studentka z monosomią chromosomu X, studiując na kierunku humanistycznym lub społecznym? Prawdopodobnie spotka się z podobnymi pseudo-medycznymi mitami, o których słuchała na lekcjach biologii w gimnazjum i liceum. Przyjrzyjmy się dwóm podręcznikom, z których korzystają studenci pierwszego roku pedagogiki specjalnej. W książce Pedagogika specjalna pod redakcją Władysława Dykcika zespół Turnera pojawia się w rozdziale dotyczącym niepełnosprawności intelektualnej w stopniu umiarkowanym, znacznym i głębokim ${ }^{8}$. O tej wadzie genetycznej nie wspomina natomiast autorka rozdziału poświęconego lekkim postaciom osłabienia funkcji umysłowych. Czytelnik podręcznika może dojść do wniosku, że zespół Turnera prowadzi zwykle do poważnych deficytów w omawianej sferze. Monosomia chromosomu X zostaje wymieniona obok innych aberracji chromosomalnych, nie zostaje jednak bliżej scharakteryzowana.

W książce Renaty Szczepanik Elementy pedagogiki specjalnej zespół Turnera zostaje zdefiniowany jako „wada genetyczna powstała wskutek uszkodzenia lub całkowitego braku chromosomu X, co powoduje określone konsekwencje jak niskorosłość, bezpłodność, szereg widocznych anomalii w budowie ciała i możliwość pojawienia się upośledzenia umysłowego"? Autorka formułuje swoje myśli ostrożnie, ostatecznie jednak nie wychodzi ponad to, co o monosomii chromosomu X można przeczytać w Tablicach Wydawnictwa Greg. Jak widzimy, w literaturze często łączy się tę wadę genetyczną z obniżoną sprawnością intelektualną, chociaż większość dotkniętych nią kobiet wykazuje normalny (przeciętny lub ponadprzeciętny) poziom inteligencji.

\section{Zakończenie. Bioetyka okiem hobbita}

Na koniec pragnę zwrócić uwagę na jedno z niebezpieczeństw, jakie łączy się z ogólnym brakiem wiedzy w społeczeństwie na temat chorób genetycznych. Badania przeprowadzone w 11 krajach europejskich pokazują, że zdiagnozowanie zespołu Turnera w badaniach prenatalnych najczęściej prowadzi rodziców do decyzji o przerwaniu ciąży. Przyjmuje się, że na naszym

\footnotetext{
8 Zob. J. Lausch-Żuk, Pedagogika osób z umiarkowanym, znacznym i głębokim upośledzeniem umysłowym, pod red. W. Dykcika, Poznań 1998, s. 133.

9 R. Szczepanik, Elementy pedagogiki specjalnej, Łódź 2007, s. 56.
} 
184 kontynencie ofiarami aborcji pada 60-80 proc. dzieci nienarodzonych ze stwierdzoną monosomią chromosomu $\mathrm{X}^{10}$. Podobne statystyki nie były prowadzone w Polsce - to znaczy nie można stwierdzić, jaki procent ciąż ze stwierdzonym zespołem Turnera jest przerywanych. Warto jednak zwrócić uwagę na fakt, iż większość legalnie przeprowadzanych zabiegów tego rodzaju ma charakter eugeniczny. Liczba aborcji dokonywanych z powodu „uszkodzenia płodu” z każdym rokiem rośnie ${ }^{11}$.

Są to dane przerażające, szczególnie z punktu widzenia osoby obciążonej chorobą genetyczną. Jakość życia dziewcząt i kobiet z zespołem Turnera nie odbiega radykalnie od ogólnie przyjętej normy. Choroba nie łączy się z długotrwałym bólem fizycznym, nie stanowi też przeszkody w podjęciu edukacji i pracy zawodowej. Przewidywana długość życia chorych jest w dużej mierze uzależniona od występowania chorób współtowarzyszących, stanu nerek i serca we wczesnym okresie życia oraz właściwego leczenia i opieki medycznej. Bezpłodność często łączy się z bólem psychicznym, nie jest to jednak powód do przedwczesnego przerywania czyjegoś życia. Warto zauważyć, że niemożność zajścia w ciążę to w dzisiejszych czasach częsty problem. Byłoby absurdem uznać, że istnienie wszystkich osób z podobnymi kłopotami jest bezwartościowe.

Promowanie wiedzy o życiu osób genetycznie chorych może być jednym ze sposobów przeciwdziałania aborcji eugenicznej. Rodzice zwykle nie mają wykształcenia medycznego. Gdy lekarz podejrzewa chorobę u płodu i sugeruje przerwanie ciąży, pojawia się lęk przed zbliżającymi się wyzwaniami. Sytuacja staje się szczególnie trudna, jeśli przewidywana długość życia maluszka jest krótka (na przykład wystąpiła poważna wada serca). Przyszłym rodzicom potrzebna jest wiedza (wyczerpująca oraz przedstawiona $\mathrm{w}$ sposób zrozumiały), pomoc psychologiczna i kontakt $\mathrm{z}$ innymi osobami wychowującymi dzieci przewlekle chore. Zwalczanie stereotypowego myślenia o niepełnosprawności może przyczynić się do zmniejszenia lęku o przyszłość malca i reszty rodziny.

10 Zob. C. Hojbjerg Gravholt, Epidemiological, endocrine and metabolic features in Turner syndrome, „European Journal of Endocrinology” 2004 (151), s. 659.

11 Zob. Sprawozdanie Rady Ministrów z wykonywania oraz o skutkach stosowania w roku 2012 ustawy z dnia 7 stycznia 1993 r. o planowaniu rodziny, ochronie płodu ludzkiego i warunkach dopuszczalności przerywania ciąży, Tabela nr 17. Zabiegi przerwania ciąży dokonane w latach 2002-2012 według przyczyn, s. 77. 


\section{Persecutions or science? Woman with Turner syndrome}

at school and in college

When we read about old-fashioned treatment methods, we often say it's unbelievable or even ridiculous. Things that our grand-grandparents used to take as obvious and scientifical are just stereotypes for us now. But we have to confess that even today, in some situation, we present misleading information as "scientifical knowledge".

In my essay I would like to share my own experience. I am a young women with Turner Syndrome. I speak about the "truths" my classmates used to learn about people who suffer from congenital diseases and myths about Turner Syndrome I heard on lectures in college. I do not suggest that our teachers and professors intend to present lies to their students - I suggest that we should be really careful about the "truths" we teach.

Keywords: Turner syndrome, persecutions, congenital diseases, education, selective abortion

\section{Wiedza czy stereotyp? Kobieta z zespołem Turnera w szkole i na uniwersytecie}

Gdy czytamy o dawnych metodach leczenia różnych schorzeń, często wydają się nam one niewiarygodne czy nawet śmieszne. To, co dla naszych dziadków było oczywistością lub prawdą naukową, dla nas jest już tylko stereotypem. Musimy jednak przyznać, że także i nam, ludziom współczesnym, zdarza się przedstawiać mylące informacje jako „wiedzę naukową".

W mojej pracy chciałam podzielić się własnym doświadczeniem. Jestem młodą kobietą z zespołem Turnera. W niniejszym artykule przedstawiam „prawdy” o ludziach z chorobami genetycznymi, jakie przekazywano moim kolegom i koleżankom w szkołach ponadpodstawowych, a także mity dotyczące zespołu Turnera, z którymi zapoznaje się studentów na wykładach w szkołach wyższych. Nie twierdzę, że nauczyciele i wykładowcy świadomie przekazują kłamstwa na swoich zajęciach - powinniśmy jednak częściej weryfikować informacje, które prezentujemy jako prawdziwe.

Słowa kluczowe: zespół Turnera, stereotyp, choroby genetyczne, edukacja, aborcja eugeniczna

\section{Bibliografia}

Łącka K., Zespół Turnera - korelacja pomiędzy kariotypem a fenotypem, „Endokrynologia Polska" 6 (2005) 56, s. 986-993. 
186 Hojbjerg Gravholt C., Epidemiological, endocrine and metabolic features in Turner syndrome, „European Journal of Endocrinology” 2004 (151), s. 657-687.

Carel H., Illnes. The cry of flesh, Stevenage 2013.

Lausch-Żuk J., Pedagogika osób z umiarkowanym, znacznym, i głębokim upośledzeniem umysłowym, pod red. W. Dykcika, Poznań 1998.

Szczepanik R., Elementy pedagogiki specjalnej, Łódź 2007.

Tablice. Matematyka, fizyka z astronomia, chemia, geografia, biologia, Kraków 2012.

Sprawozdanie Rady Ministrów z wykonywania oraz o skutkach stosowania w roku 2012 ustawy z dnia 7 stycznia 1993 r. o planowaniu rodziny, ochronie płodu ludzkiego i warunkach dopuszczalności przerywania ciąży, druk numer 2067 z dnia 13.01.2014, Warszawa, http://www.sejm.gov.pl/Sejm7.nsf/druk.xsp?nr=2067 (dostęp: 20.02.2016). 